\title{
地下空洞における計測変位の境界要素法による三次元逆解析法
}

\section{THREE-DIMENSIONAL BACK ANALYSIS METHOD OF MEASURED DISPLACEMENTS OF UNDERGROUND OPENINGS BY MEANS OF THE BOUNDARY ELEMENT METHOD}

\author{
桜井春輔*・清水則一**・壼内達也*** \\ By Shunsuke SAKURAI, Norikazu SHIMIZU and Tatsuya TSUBOUCHI
}

\begin{abstract}
This paper presents a back analysis method for determining the complete threedimensional initial state of stress and elastic constants of the ground, from a set of displacements measured during excavation of underground openings.

The method proposed here is formulated by the boundary element method, so that it can easily be applicable to three-dimensional problems, considering the sequence of steps for excavation, and the period for installation of measuring instruments in the back analysis.

In order to verify the applicability of the proposed method, computer simulations are carried out and the numerical stability of the method is demonstrated. The effects of scattering measurement data are also discussed in relation to the accuracy of the results.

Keywords : back analysis, field measurements, underground openings, boundary element method, three dimensional problem
\end{abstract}

\section{1. まえがき}

地下空洞の掘削時の力学的挙動は当初設計の段階で十 分な精度で予測することは困難である。これは地山の力 学モデルの設定が容易ではなく, さらに, 初期応力, 力 学定数および境界条件などを当初設計の段階において定 量的に把握することが困難であることに起因している. このため, 最近, トンネルなど地下空洞の施工において は, 掘削中の挙動を計測し, その結果から当初設計に用 いられた初期応力および力学定数などのインプットデー 夕の見直しを行い, 支保工ならびに掘削方法の妥当性を 検討しながら施工する方法がとられている．この方法に よると,施工中における空洞の安定性の確保だけでなく, 必要に応じて設計変更を合理的に行うことも可能とな る.しかし，この方法が有効に機能するためには計測の 結果を迅速に評価し, 設計・施工へ的確にフィードバッ クする方法が確立されなければならない.この目的のた

* 正会員 Ph. D., 工博 神戸大学教授 工学部土木工学 科

（６57 神戸市灌区六甲台町 1-1)

** 正会員 工修 神戸大学助手 工学部土木工学科 (同上)

*** 正会員工修 東急建設 (株) 技術研究所 (元神戸大学 大学院工学研究科修士課程学生)
めに最近では，空洞掘削時に行う現場計測の結果から， 地山の初期応力や力学定数などを推定する解析手法が提 案されている ${ }^{1) ~ 3)}$. これは通常の解析の逆の手順となる ため,一般に“逆解析”とよばれている.

著者の一人は, 先にトンネル掘削時の地山の測定変位 から初期応力および弾性係数を求める逆解析法を提案し た ${ }^{1)}$. それは現場への適用の容易さを第一に考慮して開 発されたものであり, 地山を等方等質線形弾性体とみな し, 有限要素法によって定式化されている。この計算プ ログラム (DBAP) は取扱いが容易であり, さらにマ イクロコンピュータによっても演算が可能なため4), す でに多くのトンネル工事で利用されている5.

この逆解析法は理論的には三次元問題に対しても拡張 可能であるが, 有限要素法によって定式化されているた め実用的にはその適用は二次元問題に限定される.しか し, 空洞掘削の状況をより現実に近い形で考慮するため には, 三次元問題として逆解析を行う必要がある. そこ で, 本論文では, この逆解析法を三次元境界要素法を用 いて定式化し，掘削手順および計測の遅れを容易に取り 扱えるように拡張する。一方, 逆解析において, 解の安 定性がしばしば問題となる.すなわち, 問題によっては 安定した解が求められない場合がある. そこで, 本研究 では, 数值シミュレーションによって, 提案する逆解析 
法の解の安定性を調べる.

なお，境界要素法は周知のように，三次元問題の解析 に有利な数值計算法であり，近年急速に発展し，地盤工 学の問題にも多数適用されている(6) -8). 逆解析の分野に おいては, 二次元を対象に，空洞の最適形状の決定 ${ }^{9}$, 異方弾性体の弾性定数の同定 ${ }^{10)}$, 最適計測パターンの検 討 ${ }^{11)}$, 非均質体の弾性定数之その境界形状の同定 ${ }^{12}$ およ び地盤内にある空洞の形状推定 ${ }^{13)}$ などが発表されてい る.

\section{2. 逆解析の目的および仮定}

本逆解析の目的は，地下空洞掘削時の変位計測の結果 から三次元状態にある地山の初期応力および力学定数を 求めることである．本逆解析では次の仮定を設ける.

（1）地山の力学モデルは等方等質の線形弾性体とす る. したがって, 逆解析によって求める力学定数はポア ソン比および弾性係数の 2 個となる.

（2）地山に作用している初期応力は空洞掘削地点に おいて一定とする.したがって, 求めるべき初期応力の 成分は 6 個となる (Fig. 1 参照).

ここで注意しなければならないことは，以上の仮定は 複雑な地山の材料定数および初期応力状態の第一近似之 して導入したことである.したがって，ここで定義した 弾性定数は非線形な非弾性挙動を含めた等価な値とし て，また，初期応力は空洞全体を含むような巨視的に捉 えた值として評価されるものであり,真に仮定(1),( 2 ) を満足する地山のみを対象としているのではない.

\section{3. 境界要素法による三次元逆解析の定式化}

\section{（1）基礎式の誘道}

境界要素法には直接法 (Direct method) と間接法 (Indirect method) があるが ${ }^{14)}$,三次元問題においては, 一般に，直接法の方が間接法より効率よく高精度の解を 得ることができるので15)，ここでは直接法を用いて逆解 析の基礎式の誘導を行う。なお，本論文では圧縮成分を

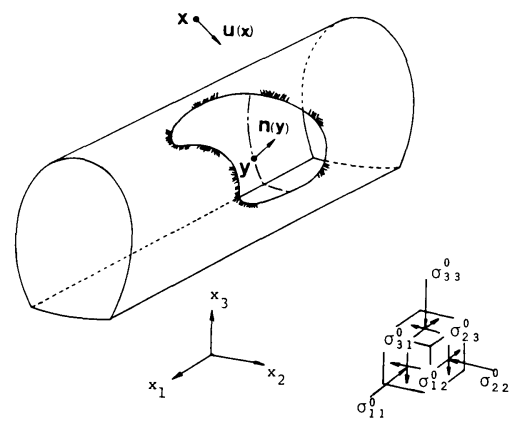

Fig. 1 Displacements and initial stress around an underground opening.
正とする.

Fig. 1 に示すように，地山を無限に広がる弾性体とす ると, 空洞掘削時に生じる地山の変位 $\boldsymbol{u}(\boldsymbol{x})$ は次のよ うに表わされる.

$$
u(x)=\int_{s} U(y, x) t(y) d S_{y}-\int_{s} T_{y}(y, x) u(y) d S_{y}
$$

上式は Somigliana の式的として知られている。たた し, $\boldsymbol{U}(\boldsymbol{y}, \boldsymbol{x})$ は変位の基本解であり, 本研究では Kelvin 解 ${ }^{17)}$ を用いる. また, $\boldsymbol{T}_{\boldsymbol{y}}(\boldsymbol{y}, \boldsymbol{x})$ は Kelvin 解に 対応する traction の基本解である. $\boldsymbol{t}(\boldsymbol{y})$ は空洞表面 $S$ の traction であり, 初期応力を $\sigma^{0}=\left\{\sigma_{11}^{0} \sigma_{22}^{0} \sigma_{33}^{0} \sigma_{23}^{0} \sigma_{31}^{0} \sigma_{12}^{0}\right\}^{T}$ とすると次のように表わされる.

$$
\boldsymbol{t}(\boldsymbol{y})=-\boldsymbol{N}(\boldsymbol{y}) \boldsymbol{\sigma}^{0} \text {. }
$$

ここで, $\boldsymbol{N}(\boldsymbol{y})$ は点 $\boldsymbol{y}$ における掘削面の単位法線べク

トル $\boldsymbol{n}(\boldsymbol{y})$ (地山から空洞内部へ向く）より構成される 行列である.

$$
\boldsymbol{N}(\boldsymbol{y})=\left[\begin{array}{cccccc}
n_{1}(\boldsymbol{y}) & 0 & 0 & 0 & n_{3}(\boldsymbol{y}) & n_{2}(\boldsymbol{y}) \\
0 & n_{2}(\boldsymbol{y}) & 0 & n_{3}(\boldsymbol{y}) & 0 & n_{1}(\boldsymbol{y}) \\
0 & 0 & n_{3}(\boldsymbol{y}) & n_{2}(\boldsymbol{y}) & n_{1}(\boldsymbol{y}) & 0
\end{array}\right]
$$

ただし， $\left.n_{i}(\boldsymbol{y}) （ i=1,2,3\right)$ は法線ベクトル $\boldsymbol{n}(\boldsymbol{y})$ の 成分である。

式（1）において, $\boldsymbol{x} \rightarrow \boldsymbol{y}_{0} \in S$ の極限操作を行うと, 次の積分方程式を得る.

$$
\begin{aligned}
& C\left(y_{0}\right) u\left(y_{0}\right)+f_{s} T_{y}\left(y, y_{0}\right) u(y) d S_{y} \\
& =-\int_{s} U\left(y, y_{0}\right) \boldsymbol{N}(y) \sigma^{0} d S_{y}
\end{aligned}
$$

ここで, $\boldsymbol{C}\left(\boldsymbol{y}_{0}\right)$ は点 $\boldsymbol{y}_{0}$ において $S$ が滑らかな場合, $1 / 2$ ・ $\boldsymbol{I}\left(\boldsymbol{I}\right.$; 単位行列) となり, 滑らかでない場合, 点 $\boldsymbol{y}_{0} に$ おける表面 $S$ の角の状態およびポアソン比によって定 まる定数となる ${ }^{18}$. また, $f_{s} \cdot d S_{y}$ はコーシーの主值積 分を表わす。

式（1）および（4）を適当に離散化し，式（2）を 考慮すると，これらはそれぞれ次のように表わすことが できる.

$$
\begin{aligned}
& \boldsymbol{u}(\boldsymbol{x})=-\boldsymbol{g}^{\prime}(\boldsymbol{x}) \boldsymbol{\sigma}^{0}-\boldsymbol{h}^{T}(\boldsymbol{x}) \underline{\boldsymbol{u}} \\
& \boldsymbol{H} \underline{u}=-\boldsymbol{G}^{\prime} \boldsymbol{\sigma}^{0} \ldots \ldots \ldots \ldots \ldots \ldots \ldots \ldots \ldots
\end{aligned}
$$

ただし, $\underline{u}$ は空洞表面の変位であり,また, $\boldsymbol{g}^{\prime}(\boldsymbol{x}), \boldsymbol{h}(\boldsymbol{x})$, $\boldsymbol{H}$ および $\boldsymbol{G}^{\prime}$ は式（1）および（4）を離散化して得ら れるベクトルと行列である.なお，・而は転置を表わす， 式（5）および（6）より $\underline{\boldsymbol{u}}$ を消去すると次の式を得る.

$$
\boldsymbol{u}(\boldsymbol{x})=\boldsymbol{f}^{T}(\boldsymbol{x}) \boldsymbol{\sigma}^{0}
$$

ただし，

$$
\boldsymbol{f}^{T}(\boldsymbol{x})=\boldsymbol{h}^{T}(\boldsymbol{x}) \boldsymbol{H}^{-1} \boldsymbol{G}^{\prime}-\boldsymbol{g}^{\prime T}(\boldsymbol{x})
$$

である.ここで, 初期応力 $\sigma^{0}$ を弾性係数 $E$ で除し, こ れを $\sigma^{0 *}=\left\{\begin{array}{llllll}\sigma_{11}^{0} / E & \sigma_{22}^{0} / E & \sigma_{33}^{0} / E & \sigma_{23}^{0} / E & \sigma_{31}^{0} / E & \left.\sigma_{12}^{0} / E\right\}^{T}\end{array}\right.$ 
と表わすと, 式 $(7)$ は次のように書ける.

$$
\boldsymbol{u}(\boldsymbol{x})=\boldsymbol{f}^{* T}(x) \sigma^{0 *}
$$

ただし

$$
\boldsymbol{f}^{* T}(\boldsymbol{x})=E \cdot \boldsymbol{f}^{T}(\boldsymbol{x})
$$

である. 式（8）は本逆解析法の基礎式である.なお, $\boldsymbol{f}^{*}(\boldsymbol{x})$ は点 $\boldsymbol{x}$ の関数であり, 空洞の形状およびポアソ ン比に関係するが $E$ には無関係となる．ここで， $\sigma^{0 *}$ は初期応力パラメーター (normalized initial stress) と よぶ.

なお，本逆解析は境界要素法に基づくため，要素分割 は空洞表面についてのみ行えばよく，また，地山内部の 変位は式 $(8)$ を用いて必要な点についてのみ計算すれ ばよい, 一方, 有限要素法を用いて式 $(8)$ を導く場合, 点 $x$ をあらかじめ有限要素の節点として考慮しなけれ ばならず, 点 $x$ を変位の計測点と考えれば, 計測点の 位置に要素分割が左右されることになる．任意点の変位 を式（8）を用いて容易に求めることができるのは境界 要素法を用いた利点である.

\section{（2）初期応力および弾性係数の逆解析}

計測変位と初期応力パラメーターの関係式は, 式 $(8)$ を用いて次のように求められる。

$$
\boldsymbol{u}_{m}=\boldsymbol{F} \boldsymbol{\sigma}^{0 *}
$$

ただし，F は $\boldsymbol{f}^{*}(\boldsymbol{x})$ より構成される行列である. 地山 のポアソン比は逆解析によって求めるべき力学定数であ るが，後に述べるように逆解析結果に及ぼす影響が小さ いため，ここではその值を既知と考える.

もし, 独立した計測変位の数が 6 個あれば, 式 $(9)$ は 6 元連立方程式となり， $\boldsymbol{\sigma}^{0 *}$ は一意的に求められる. また, 計測変位が 6 個以上あれば， $\sigma^{0 *}$ は最小二乗法を 用いて次のように求められる.

$$
\boldsymbol{\sigma}^{0 *}=\left(\boldsymbol{F}^{T} \boldsymbol{F}\right)^{-1} \boldsymbol{F}^{T} \overline{\boldsymbol{u}}_{\boldsymbol{m}}
$$

ただし， $\overline{\boldsymbol{u}}_{m}$ は測定変位である。

ここで, 初期応力の一成分が与えられるならば， $\sigma^{0 *}$ から地山の弾性係数および初期応力の他の成分を求める ことができる.したがって，何らかの方法でこれを推定 する必要がある，たとえば，初期応力の鉛直成分を土被 り圧,

$$
\sigma_{33}^{0}=\gamma h(\gamma \text {; 地山の平均的な単位体積重量, }
$$$$
h ; \text { 土被り厚さ) }
$$

に等しいと仮定すれば, 弾性係数およびその他の初期応 力の成分の值はすべて求められる. しかし，本逆解析に よって得られる初期応力および弾性係数を, 次以降の掘 削における地山の変形挙動の予測解析のインプットとし て用いるならば，これらを分離する必要はなく，初期応 カパラメーターを直接用いればよい.

ところで, 式 $(8)$ は空洞掘削によって生じる全変位 を表わす。しかし，実際には変位計测器は空洞がある程

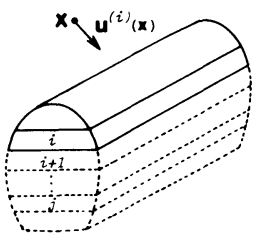

(a)

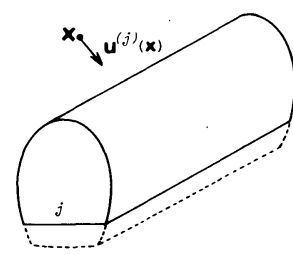

(b)
Fig. 2 Displacements caused by excavation at : (a) the $i$ th stage, and ( $\mathrm{b}$ ) the $j$ th stage.

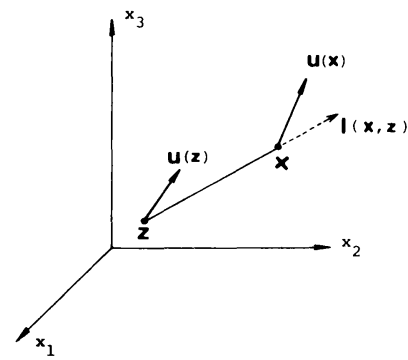

Fig. 3 Displacement vectors at two adjacent points.

度掘削された後に設置されるため, 計測開始以前の変位, いわゆる先行変位が存在する.また, 計測される変位は 絶対変位ではなく計測点間の相対変位であることが多 い. 本逆解析法においては，これらのことを以下のよう に考慮することができる.まず，点 $x$ において，第 $i$ 段階掘削終了までに生じた変位 (Fig. 2 参照) を式 (8) を参考にして次のように表わす.

$$
u^{(i)}(x)=f^{*(i) T}(x) \sigma^{0 *}
$$

第 $i$ 段階掘削終了時に設置した変位計によって, 第 $j$ 段階終了 $(i<j)$ までに测定される変位は次のように 書ける.

$$
\boldsymbol{u}^{(j-i)}(x)=\boldsymbol{u}^{(j)}(\boldsymbol{x})-\boldsymbol{u}^{(i)}(\boldsymbol{x})
$$

さらに, 点 $x$ と点 $z$ 間を結ぶ方向の両点間の相対変位 は, 微小変位の場合次の式で求められる (Fig. 3 参照).

$$
\Delta \boldsymbol{u}^{(j-i)}(x, z)=\boldsymbol{l}^{T}(x, z)\left[\boldsymbol{u}^{(j-i)}(x)-\boldsymbol{u}^{(j-i)}(z)\right]
$$
ただし, $\boldsymbol{l}(\boldsymbol{x}, \boldsymbol{z})$ は点 $\boldsymbol{x}$ と $\boldsymbol{z}$ を結ぶ直線の単位方向 ベクトルである. 式（14）を新たに逆解析の基礎式とす ることによって, 掘削段階および相対変位を考慮した逆 解析が容易に行える.

\section{4. 解析結果の精度と安定性の検討}

\section{（1）数値計算の精度}

本研究では, 8 節点アイソパラメトリック曲面要素を 用いた境界要素法 ${ }^{19)}$ によって解析する。 まず，ここで 開発した解析プログラムの精度を検証するために, Fig. 4 (a) に示す球形空洞の掘削問題を解析する. 要 素分割はFig. 4 ( b ) に示すように 24 要素 (74 節点) 
とした．初期応力は $\sigma_{33}^{0}=p$ および他の成分は 0 の一軸 状態とし，ポアンン比は $\nu=0.3$ である. Fig. 5 は厳密 解と境界要素法による変位の比較である．正解値との誤 差は最大でも約 $2 \%$ 前後であり，ここで開発した解析 プログラムは十分な精度を有しているものと判断でき る.

\section{（2）ポアソン比の影霎}

本研究では, 地山のポアソン比を仮定して逆解析を行 うため, 逆解析結果に及ぼすポアソン比の影響の程度を 検討しておく必要がある。ここでは前出の球形空洞掘削 問題を例にとり，初期応力 $\sigma^{0}=\left\{\begin{array}{l}6.0 \\ \text { ( } 0.07 .02 .51 .5\end{array}\right.$ 3. $0 r^{r}(\mathrm{MPa})$, また, 弾性係数 $E=5.0 \mathrm{GPa}$ として, 数 值シミュレーションによって検討する.なお，ポアソン 比は $0.1 \sim 0.4$ の範囲を考える. シミュレーションは上 記の諸値に対する厳密解を “測定変位”として逆解析を 行い，ポアソン比を適当に仮定し，そのときの初期応力 パラメーターの誤差を求めるものである。計測点は Fig. 6 に示すように 9 点とし，各点において $x_{1}, x_{2}, x_{3}$ 軸方向三成分とも測定されるものとする．Fig.7にポア

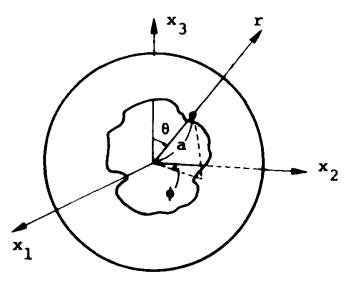

(a)

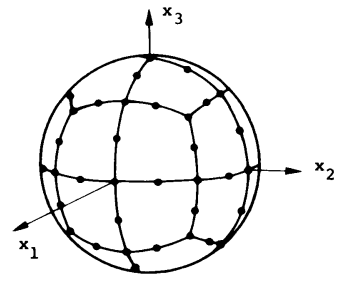

(b)
Fig. 4 Coordinate system and boundary element discretization of a spherical cavity.

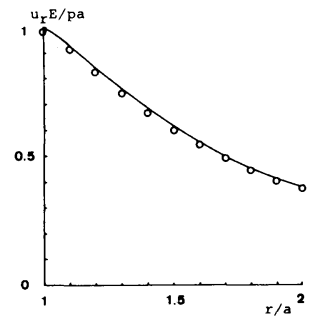

(a)

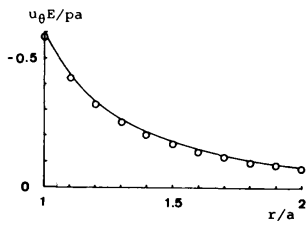

(c)

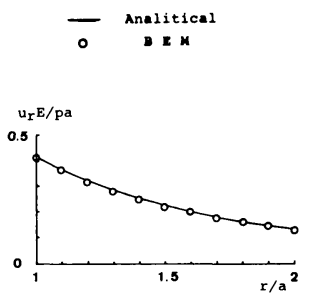

(b)

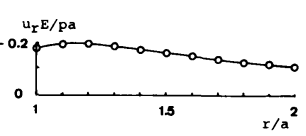

(d)
Fig. 5 Displacements around a spherical cavity : ( a ) radial $\left(\theta=0^{\circ}\right),(\mathrm{b})$ radial $\left(\theta=45^{\circ}\right),(\mathrm{c})$ tangential $(\theta=$ $\left.45^{\circ}\right)$, ( d ) radial $\left(\theta=45^{\circ}\right)$ displacements.

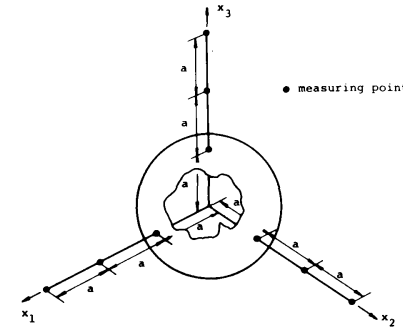

Fig. 6 Measuring points of displacement in the vicinity of a spherical cavity.

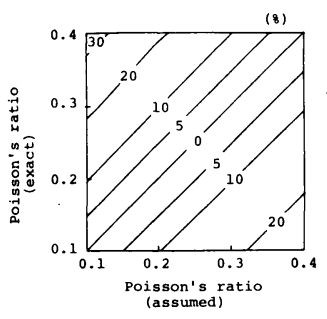

(a)

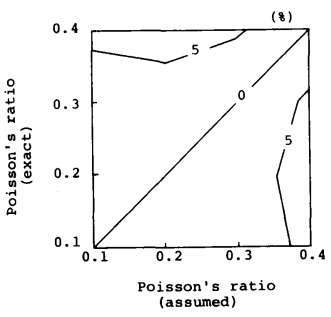

Fig. 7 Relative error of the normalized initial stress under the assumption of Poisson's ratio : ( a ) $\sigma_{11}^{0} / E$ (b) $\sigma_{23}^{0} / E$.

ソン比を仮定したことによる初期応力パラメーター $\sigma_{11}^{0} / E$ および $\sigma_{23}^{0} / E$ の相対誤差 $(\%)$ を示す。この図 から，たとえば，真のポアソン比が 0.25 の場合， $\nu=$ $0.15 \sim 0.35$ の範囲で仮定すれば， $\sigma_{11}^{0} / E$ は $10 \%$ 内の誤 差で求められることがわかる. なお，他の成分 $\sigma_{22}^{0} / E$ および $\sigma_{33}^{0} / E$ は $\sigma_{11}^{0} / E$ と，また， $\sigma_{31}^{0} / E$ および $\sigma_{12}^{0} / E$ は $\sigma_{23}^{0} / E$ とほぼ同程度の相対誤差であることが明らか となった．結局，ポアソン比を仮定することによって生 じる誤差は最大 20 - 30 \% 程度であるといえる，一方， ポアソン比は一般に，岩質によって定まると考えられる ので概略值は比較的容易に推定される，たとえば，硬質 岩盤では 0.2 , 軟質岩盤では 0.4 が用いられている20121). したがって，実際には誤差はさらに小さくなると考えら れる.

（３）数值シミュレーションによる逆解析解の安定性 の検討

逆解析では，一般に解の安定性が保証されていないた め, 測定值の変動が解に大きく影響を及ぼす可能性があ る. 地下空洞の施工中に測定される変位は種々の要因に よってばらついていることが多く，したがって，本研究 においても解の安定性を調べておく必要がある．ここで は, 数值シミュレーションにより, 逆解析によって求め られる初期応力パラメーターの安定性について検討す る.

解析は Fig. 8 に示す地下空洞について, 掘削手順およ 
び変位計測器の設置時期を考慮して行う。すなわち, 掘 削は 4 段階とし(第 4 段階は最終掘削), Table 1 に示 すように1 3 段階掘削終了時にそれぞれの変位計を設 置し，逆解析は空洞掘削終了時に行うものとする．ただ

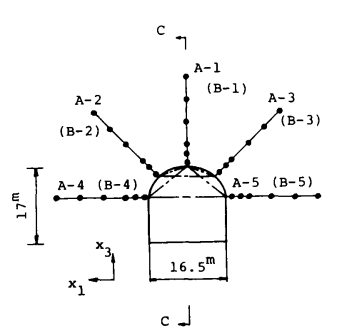

(a)

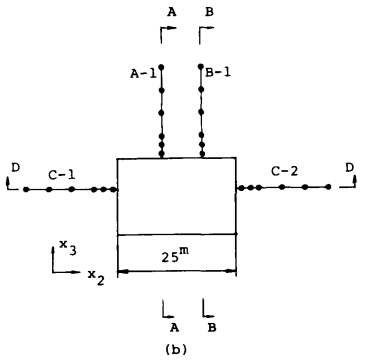

- borehole extensometer

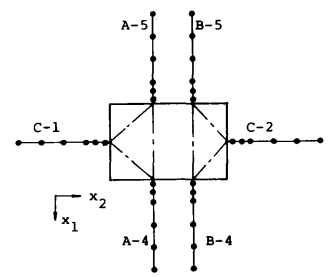

(c)

Fig. 8 Configuration of an underground opening and location of measuring points : ( a ) section $\mathrm{A}$ and $\mathrm{B}$, ( $\mathrm{b}$ ) section $C$, ( c ) section D.

Table 1 Excavation steps and installation of measuring instruments.

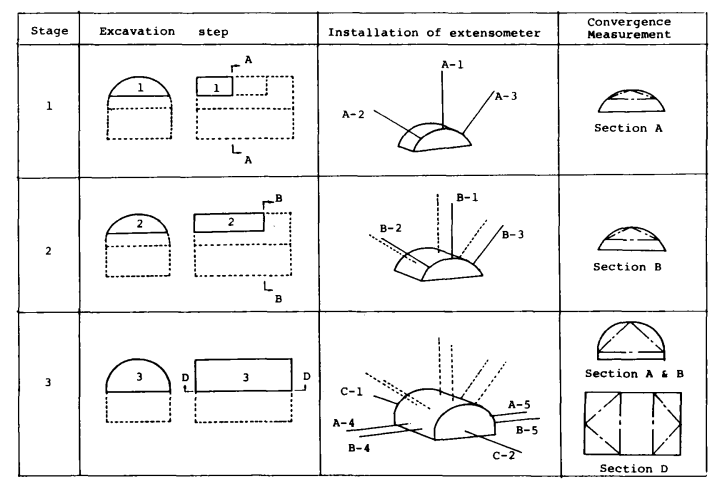

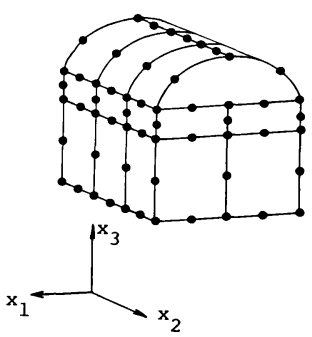

Fig. 9 Boundary element discretization of the underground opening.

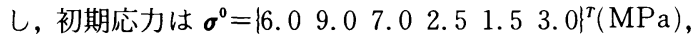
弾性係数およびポアソン比はそれぞれ，E=5.0 GPa お よび $\nu=0.3$ とする.なお, 空洞の境界要素分割は Fig. 9 に示すとおりである.まず，通常の解析を行い， 各測点の変位を求める.この変位を用いて逆解析を行え ば当然, 正解の初期応力パラメーター $\sigma^{0 *}=\{1.21 .8$ $1.40 .50 .30 .6\}^{T} \times 10^{-3}$ を得る. そこで, 解析によっ て得たすべての変位において $1 / 10 \mathrm{~mm}$ の位を四捨五入 し，これを“測定変位”として逆解析を行う.たとえば, A-1の地中変位（壁面から最も奥の測点と各点間の相 対変位)については次のように与える.

$$
\left(\begin{array}{l}
6.5763 \\
4.9740 \\
3.5951 \\
2.6887 \\
1.1819 \\
0.4338
\end{array}\right)_{\mathrm{mm}} \rightarrow \quad\left(\begin{array}{l}
7.0 \\
5.0 \\
4.0 \\
3.0 \\
1.0 \\
0.0
\end{array}\right)_{\mathrm{mm}}
$$

（通常の解析による変位）（1/10mm の位を四捨五入

$$
\text { した“計測変位”) }
$$

このとき, 逆解析によって得られる初期応力パラメー ターは Table 2 に示す值となり, 誤差は高々数％とな る.したがって,この程度の測定変位のばらつきに対し ては，本逆解析法は十分安定した解を与えるといえる. なお，本解析例ではポアンン比を 0.3 としている.

解の安定性をもう少し一般的に議論するために, 測定 変位のばらつきについて次のような仮定を与える．すな わち, “測定変位” は弾性変位解を平均値とし, ある変 動係数に従ってばらついているものとする．この仮定の もとで, 解の安定性を表わす指標を与える．いま，“測 定変位”のばらつきが互いに独立であるとすれば, 初期 応力パラメーターの変動係数は式（10）に誤差伝幡の法

Table 2 Results of back analysis carried out on a numerical example.

\begin{tabular}{|c|c|cc|}
\cline { 2 - 4 } \multicolumn{1}{c|}{} & Exact $\left(\times 10^{-3}\right)$ & Back analysis $\left(\times 10^{-3}\right)$ \\
\hline$\sigma_{11} \% \mathrm{E}$ & 1.2 & 1.21 & {$[0.6]$} \\
\hline$\sigma_{22} \% \mathrm{E}$ & 1.8 & 1.82 & {$[1.0]$} \\
\hline$\sigma_{33} \% \mathrm{E}$ & 1.4 & 1.41 & {$[1.0]$} \\
\hline$\sigma_{23} \% \mathrm{E}$ & 0.5 & 0.49 & {$[1.5]$} \\
\hline$\sigma_{31} \% \mathrm{E}$ & 0.3 & 0.30 & {$[0.1]$} \\
\hline$\sigma_{12} \% \mathrm{E}$ & 0.6 & 0.62 & {$[4.0]$} \\
\hline
\end{tabular}

[ ]; relative error (z)

Table 3 Index $V_{i}$ for evaluating the stability

\begin{tabular}{|c|c|}
\hline$v_{1}\left(\sigma_{11}{ }^{0} / E\right)$ & 0.24 \\
\hline$v_{2}\left(\sigma_{22}{ }^{\circ} / E\right)$ & 0.41 \\
\hline $\mathrm{v}_{3}\left(\sigma_{33}{ }^{0} / \mathrm{E}\right)$ & 0.29 \\
\hline $\mathrm{v}_{4}\left(\sigma_{23}{ }^{0} / \mathrm{E}\right)$ & 0.97 \\
\hline$v_{5}\left(\sigma_{31}{ }^{0} / E\right)$ & 0.51 \\
\hline $\mathrm{v}_{6}\left(\sigma_{12}{ }^{0} / \mathrm{E}\right)$ & 0.92 \\
\hline
\end{tabular}
of back analysis. 
則を適用して次のように求められる (付録参照).

$$
S_{i}=\left(\sum_{j=1}^{M} A_{i j}^{2} \bar{u}_{j}^{e 2}\right)^{1 / 2} \cdot S_{u} /\left|\sum_{j=1}^{M} A_{i j} \bar{u}_{j}^{e}\right|
$$

ただし，変動係数 $S_{i}(i=1,2, \cdots, 6)$ はそれぞれ初 期応力パラメーター $\sigma_{11}^{0} / E, \sigma_{22}^{0} / E, \sigma_{33}^{0} / E, \sigma_{23}^{0} / E, \sigma_{31}^{0} / E$, $\sigma_{12}^{0} / E$ に対応している. また, $M$ は計測数, $A_{i j}$ は式 (10) における $\left(\boldsymbol{F}^{T} \boldsymbol{F}\right)^{-1} \boldsymbol{F}^{T}$ の成分, $\bar{u}_{j}^{e}$ は弾性変位解, さらに, $S_{u}$ は “測定変位” の変動係数である.ここで，初期応 力パラメーターの変動係数と“測定変位” の変動係数の 比を $V_{i}$ とする.

$$
V_{i}=S_{i} / S_{u}
$$

$V_{i}$ はインプットとしての “測定変位”のばらつきが解 である初期応力パラメーターのばらつきに及ぼす影響の 程度を表わすものと考えられるので，これを解の安定性 を表わす指標とおくことができる．すなわち， $V_{i}>1.0$ の場合, “測定変位”のばらつきは拡大され，解は不安 定となる傾向にあり, 逆に $V_{i}<1.0$ の場合, “測定変位” のばらつきは縮小され，解は安定する傾向にある．変動 係数比 $V_{i}$ を先の解析例（Fig. 8 および Table 1) につい て計算すると Table 3 に示す値となる。この結果， $V_{i}$ はいずれも 1 以下となり，測定変位のばらつきは解にお いて縮小されることがわかる.

以上より，ここで取り上げたような変位のばらつきに 対して, 本逆解析法は安定した解 (初期応力パラメ一 ター）を与えるものと判断される.

\section{5. むす び}

本論文では, 現場計測変位から地山の初期応力および 弾性係数を求めることのできる三次元逆解析法を境界要 素法によって定式化した。さらに，解の安定性について， 計算機による数值シミュレーションを用いて考察した. 本論文は次のように取りまとめられる。

（1）本逆解析によって，地山の初期応力および弾性 係数を同時に求めることができる。なお，ポアソン比は 逆解析によって求めるべき力学定数であるが，解に及ぼ す影響が小さいことを考慮して，あらかじめ仮定する.

（2）境界要素法を用いると，要素分割は解析領域の 境界においてのみ行われるため, 変位の計測点に関係な く要素分割が行うことができる．このため，有限要素法 による方法と比較して，逆解析が著しく容易となる.

（３）ここで提案した逆解析法は, 三次元問題として 定式化しているため, 掘削段階や計測遅れなどを考慮し, 現実に近い状態で解析を行うことができる。

（4）本逆解析による解の安定性を調べるため, 数值 シミュレーションを行った. その結果, 本研究で考察し たようなばらつきを有する“測定変位”に対して，解は 安定することが示された。
最後に，数値計算の一部についてご援助頂いた神戸大 学大学院工学研究科学生 横野勇人君に感謝致します.

\section{付録 式（15）の誘導}

式（10）を次のように書き直す.

$$
\left|\begin{array}{c}
\sigma_{11}^{0} / E \\
\sigma_{22}^{0} / E \\
\sigma_{33}^{0} / E \\
\sigma_{23}^{0} / E \\
\sigma_{31}^{0} / E \\
\sigma_{12}^{0} / E
\end{array}\right|=[A]\left|\begin{array}{c}
\bar{u}_{1} \\
\bar{u}_{2} \\
\cdot \\
\cdot \\
\cdot \\
\bar{u}_{M}
\end{array}\right|
$$

ただし， $[A]=\left(\boldsymbol{F}^{T} \boldsymbol{F}\right)^{-1} \boldsymbol{F}^{T}, \bar{u}_{i}$ は測定変位および $M$ は その数である.ここでは, $\sigma_{11}^{0} / E$ の変動係数を誘導する。

まず， $\sigma_{11}^{0} / E$ は式 $(\mathrm{A} \cdot 1)$ より次のように書ける.

$$
\sigma_{11}^{0} / E=\sum_{j=1}^{M} A_{1 j} \bar{u}_{j}
$$

$\sigma_{11}^{0} / E$ の分散は式 $(\mathrm{A} \cdot 2)$ より次のようになる.

$$
\operatorname{Var}\left(\sigma_{11}^{0} / E\right)=\sum_{j=1}^{M} A_{1 j}^{2} \operatorname{Var}\left(\bar{u}_{j}\right)
$$

ただし，測定変位は互いに独立と考えている．一方，測 定変位の分散は，「“測定変位”は弾性変位解 $\left(\bar{u}_{j}^{e}\right)$ を 平均值とし，ある変動係数 $\left(S_{u}\right)$ に従ってばらついて いる」と考えているので，次のように表わされる。

$$
\operatorname{Var}\left(\bar{u}_{j}\right)=\left(\bar{u}_{j}^{e} \cdot S_{u}\right)^{2}
$$

また, $\operatorname{Var}\left(\sigma_{11}^{0} / E\right)$ は $\sigma_{11}^{0} / E$ の平均值 $\mathrm{E}\left(\sigma_{11}^{0} / E\right)$ および 変動係数 $S_{1}$ を用いて次のように表わされる.

$\operatorname{Var}\left(\sigma_{11}^{0} / E\right)=\left(\mathbf{E}\left(\sigma_{11}^{0} / E\right) \cdot S_{1}\right)^{2} \cdots \ldots \ldots \ldots \ldots \ldots(\mathrm{A} \cdot 5)$ 式 $(\mathrm{A} \cdot 4)$ および $(\mathrm{A} \cdot 5)$ を式 $(\mathrm{A} \cdot 3)$ に代入し，さ らに,

$$
\mathrm{E}\left(\sigma_{11}^{0} / E\right)=\sum_{j=1}^{M} A_{1 j} \bar{u}_{j}^{e}
$$

を考慮すると, $\sigma_{11}^{0} / E$ の変動係数は次のように求められ る.

$$
S_{1}=\left(\sum_{j=1}^{M} A_{1 j}^{2} \bar{u}_{j}^{e 2}\right)^{1 / 2} \cdot S_{u} /\left|\sum_{j=1}^{M} A_{1 j} \bar{u}_{j}^{e}\right|
$$

初期応力パラメーターの他の成分の変動係数も同様にし て求められる.

\section{参 考 文 献}

1) 桜井春輔・武内邦文：トンネル掘削時における変位計測 結果の逆解析法, 土木学会論文報告集, 第 337 号, pp. $137 \sim 145,1983$

2）荒井克彦・片瀬貴文：トンネル内空変位計測に基づく地 盤変形 強度定数の推定, 土質工学会論文報告集, Vol. 24, No. 2, pp. 171 179, 1984.

3）久武勝保 - 伊藤富雄 - 加藤茂樹 - 真鍋幸一郎：最適化手 法を用いた三次元逆解析法とその現場への適用, 第 6 回 岩の力学国内シンポジウム講演論文集, pp. 215 220, 1984

4) 桜井春輔・進士正人：マイクロコンピュータによる地下 空洞掘削時の安定性の評価, 土木学会論文集, 第 358 号 
/III-3, pp. 37〜46, 1985.

5）たとえば，長谷川滋・佐藤正人・岡本伸一：熟羽山トン ネルの施工 ( 2 )一鉄道トンネルの計測結果, トンネルと 地下, 第 16 巻 10 号, pp. 7 14, 1985.

6) Banerjee, P.K. and Butterfield, R. : Boundary Element Methods in Geomechanics, Finite Elements in Geomechanics (ed. by G. Gudehus), John Wiley \& Sons, chap. 16, pp. 529 570, 1977.

7) Kobayashi, S. : Applications of Boundary Integral Equation Method to Geomechanics, Proc. 5 th Int. Conf. on Numerical methods in Geomechanics, Vol.1, pp. 83 92, 1985.

8) Venturini, W.S. : Boundary Element Method in Geomechanics, Springer-Verlag, 1983.

9) Kobayashi, S., Nishimura, N. and Yoshida, K. : Applications of Boundary Integral Equation Method to Changing Boundary Shape Problems, Proc. 3 rd Int. Conf. on Numerical Methods in Geomechanics, pp. 39 46, 1979.

10) Hermans, Ph., De Wilde, W. P. and Hiel, Cl. : Boundary Integral Equations Applied in the Characterization of Elastic Materials, Proc. Int. Conf. on Computational Methods and Experimental Measurements, pp.189 199, 1982.

11) Shimizu, N. and Sakurai, S. : Application of Boundary Element Method for Back Analysis Associated with Tunnelling Problems, Proc. 5 th Int. Conf. on Boundary Elements, pp. 645 654, 1983.

12）大西有三・東出明宏: 不均質岩盤の弾性定数と幾何学的 特性の同定に関する基礎的研究，土木学会論文集，第
358 号 $/$ III -3 , pp. 93 101， 1985.

13）丹羽義次・広瀬壮一：超音波法による弾性体内の空洞形 状の決定について，土木学会関西支部年次学術講演会講 演概要集, I-21, 1984.

14) Banerjee, P. K. and Butterfield, R. : Boundary Element Methods in Engineering Science, McGraw-Hill, 1981.

15）清水則一・桜井春輔・壸内達也：境界要素法による三次 元静弾性問題の解析一直接法之間接法一, 建設工学研究 所報告, No. 28, pp. 63 75, 1986 .

16) Love, A.E.H. : A Treatise on The Mathematical Theory of Elasticity ( 4 th ed. ), Dover, pp. $245 \sim 246$, 1944.

17) Sokolnikoff, I.S. : Mathematical Theory of Elasticity (2 nd ed.), McGraw-Hill, pp. 337, 1956.

18) Hartmann, F. : Elastostatics, Progress in Boundary Element Methods Vol. 1 (ed. by C. A. Brebbia), Pentech Press, chap. 4, pp. 84 167, 1981.

19) Watson, J. O. : Advanced Implementation of the Boundary Element Method For Two-and Three-dimensional Elastostatics, Developements in Boundary Element Methods-1 (eds. P. K. Banerjee and R. Butterfield), Applied Science Publishers, chap. 3, pp. 31 63, 1979.

20）土木学会：原位置岩盤の変形およびせん断試験の指針一 解説之設計への適用一, 土木学会, 1983 .

21）土木学会岩盤力学委員会理論・試験小委員会 : 孔内試験 法の現状と課題一指針化の試み一，土木学会論文集，第 364 号 / III-4, pp. 15 22, 1985.

(1986.6.25・受付) 